\title{
Body Weight Evolution of Tsurcana Pure Breed Lambs and Tsurcana Crossed with Blanc Du Massif Central Lambs (F1)
}

\author{
Ioan PAȘCA ${ }^{1}$, Dana PUSTA ${ }^{1}$, Liviu BOGDAN² ${ }^{2}$ Diana ZAGON ${ }^{2}$, Anca GIURGIUMAN ${ }^{3}$, Alexandra TĂBARAN ${ }^{1}$, \\ Mihai Marian BORZAN ${ }^{*}$
}

\author{
${ }^{1}$ Department of Animal Productions and Food Safety, USAMV Cluj, Romania \\ ${ }^{2}$ Department of Clinics, USAMV Cluj, Romania \\ ${ }^{3}$ S.C.Agrocons Parox SRL \\ *corresponding author: mihai_borzan@yahoo.com
}

Bulletin UASVM Veterinary Medicine 74(1) / 2017,

Print ISSN 1843-5270; Electronic ISSN 1843-5378

DOI:10.15835/buasvmcn-vm: 12432

\begin{abstract}
The Blanc du Massif Central breed is a rustically French meat breed of sheep that was used in crossing with Tsurcana breed in order to improve the quality of local lambs for the European market. After crossing, the resulting lambs were compared with purebred Tsurcana lambs to evaluate daily weight gain from birth to 3 months. The daily weight gain was superior in the crossed lambs compared with purebred lambs.
\end{abstract}

Keywords: Blanc du Massif Central, body weight, daily weight gain, Tsurcana

\section{INTRODUCTION}

In the EU market the demand for the local breed meat, such as Tsurcana breed, is low (FAO 2014; Belibasaki, 2012; Reports of the Romanian National Agency for Genetic Improvement and Reproduction in Animal Husbandry for the year 2010); so many breeders choose to cross the pure breed ewes with meat rams to improve the quality of the lambs (Pascal et al., 2014) and so using the heterosis effect. The Blanc du Massif Central breed is a rustically French meat breed of sheep, and it was not used before in our country to produce F1 lambs for the market (Kukovics et al., 2013).

The crossing of the Tsurcana breed with a French meat breed like Blanc du Massif Central is important to increase the quality of the resulting carcasses. The Blanc du Massif Central breed has never been used before in crossings with Romanian breeds.
This is an original research and presents preliminary data regarding the carcass characteristics of the hybrid lambs resulted from the crossing of the French sheep breed with the Tsurcana purebred.

The study has been carried out from summer 2015 to autumn 2016.

The aim of this study is to evaluate the body weight evolution of the resulted lambs F1 with the body weight evolution of the pure Tsurcana lambs, daily weight gain from birth to 3 months.

$\mathrm{H}_{0}$ hypothesis = the body weight of the crossbred Tsurcana with Blanc de Massif Central and purebred Tsurcana lambs is equal, regardless of the moment when the weighting is performed (at birth, at 21, 50 and 90 days).

$\mathrm{H}_{1}$ hypothesis = the body weight of the crossbred Tsurcana with Blanc de Massif Central and purebred Tsurcana lambs is different, re- 


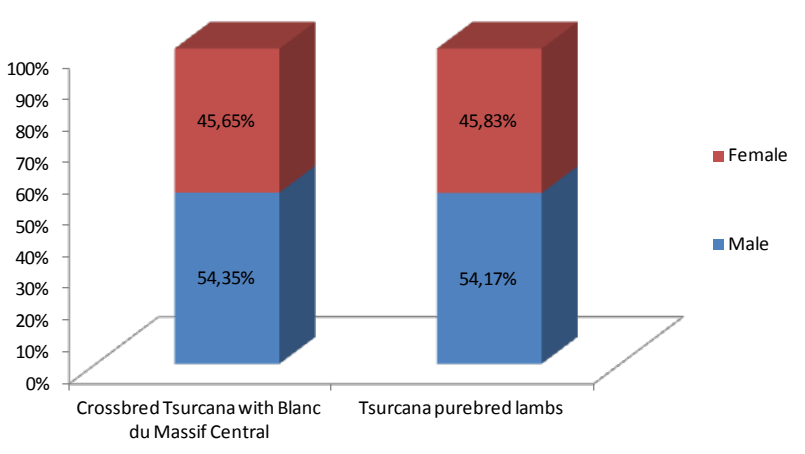

Fig 1. The share of crossbreds and purebreds lambs according to gender

gardless of the moment when the weighting is performed (at birth, at 21, 50 and 90 days).

\section{MATERIALS AND METHODS}

The research has been carried out on two selected Tsurcana batches. The first batch consisted on a flock of purebred Tsurcana lambs and the second one consisted on a flock of F1 lambs (Tsurcana ewes and BMC rams). The lambs were kept in similar conditions (nutrition, housing, etc). The body weight of the lambs was evaluated at birth, at 21, 50 and 90 days. The results were statistical evaluated using ANOVA test and t-Test, average and standard deviation.

The analysis regarded the daily weight gain, the comparative evaluation of body weight concerning the age, sex and purebred lams with F1 crossed lambs (Dodouet 2003; Mireșan et al., 1979).

\section{RESULTS AND DISCUSSION}

The BMC breed has never been used before in crossings with Tsurcana. This is an original research and presents preliminary data regarding the results of the crossings between Tsurcana breed crossed with BMC breed compared with the evolution of the purebred Tsurcana.

The research was conducted on 99 ewes that were divided in two batches.

The 50 Tsurcana ewes were synchronized and naturally mated with Blanc du Massif Central rams (batch I, test), 48 ewes were diagnosed as pregnant by ultrasound examination and only 46 crossed lambs resulted (the difference was recorded as abortion). From the second batch (control batch), 49 ewes were synchronized and naturally mated with Tsurcana rams and 48 purebred lambs resulted (the difference was recorded as abortion).

All the pregnant ewes were assisted to parturition; the resulted lambs were weighted immediately after parturition and identified in the first day after birth.

The gender share for crossbred and purebreds lambs are almost equal, more than half were males (crossbreds $54.35 \%$, respectively $54.17 \%$ to purebreds), and almost equal shares $(45,65 \%$ Tsurcana crossbreds and 45,83\% Tsurcana purebreds lambs) were females (fig 1).

Following the statistical analysis, we obtained superior results for the F1 crossed lambs compared with the purebred Tsurcana lambs concerning the daily weight gain and the body weight evolution between the two batches.

The average of body weight of crossbred lambs from the test batch (Tsurcana x BMC) are higher than those of purebred Tsurcana lambs from the control batch, regardless of the moment when the weighting is performed (at parturition, at 21 , at 50 and 90 days). The data collected revealed that the male and female crossbreds from the testing batch recorded superior weights than the purebred males and females Tsurcana lambs from the control batch (table 1, fig 2, 3)

Concerning the body weight analysis at parturition of the control batch and the test batch, the ANOVA test revealed that $\mathrm{F}>\mathrm{F}$ crit, meaning $175.51>3.94$, so the hypothesis is rejected and the $\mathrm{H}_{1}$ hypothesis is accepted according to which the body weight at parturition of the crossbred Tsurcana lambs are different that the weight of purebred Tsurcana lambs (table 2).

The t-Test confirmed that $\mathrm{t}$ Stat $\geq \mathrm{t}$ Critical two-tail, $(13.04 \geq 2.00)$, fact that reinforces the 
Tab. 1. Average and standard deviation of the body weight of the Tsurcana crossbred with Blanc du Massif Central and Tsurcana purebred lambs at parturition, 21 days, 50 days, 90 days $(\mathrm{kg})$

\begin{tabular}{ccccc}
\hline \multicolumn{5}{c}{ Crossbred Tsurcana with Blanc du Masiff Central } \\
\hline Body weight & Parturition (kg) & 21 days $(\mathrm{kg})$ & 50 days $(\mathrm{kg})$ & 90 days $(\mathrm{kg})$ \\
\hline Total testing group & $4,99 \pm 0,98$ & $10,25 \pm 2,26$ & $19,98 \pm 4,58$ & $28,48 \pm 4,38$ \\
\hline Males & $5,07 \pm 0,97$ & $10,35 \pm 2,13$ & $20,65 \pm 4,63$ & $28,40 \pm 4,60$ \\
\hline Females & $4,90 \pm 1,00$ & $10,12 \pm 2,44$ & $19,18 \pm 4,50$ & $28,56 \pm 4,21$ \\
\hline \multicolumn{5}{c}{ Tsurcana purebred lamb } \\
\hline Body weight & Parturition (kg) & 21 days $(\mathrm{kg})$ & 50 days $(\mathrm{kg})$ & 90 days $(\mathrm{kg})$ \\
\hline Total control group & $2,96 \pm 0,40$ & $7,69 \pm 0,84$ & $15,35 \pm 1,61$ & $23,90 \pm 2,02$ \\
\hline Males & $3,01 \pm 0,43$ & $7,85 \pm 0,85$ & $15,72 \pm 1,59$ & $24,55 \pm 1,83$ \\
\hline Females & $2,90 \pm 0,36$ & $7,51 \pm 0,82$ & $14,90 \pm 1,55$ & $23,15 \pm 2,01$ \\
\hline
\end{tabular}

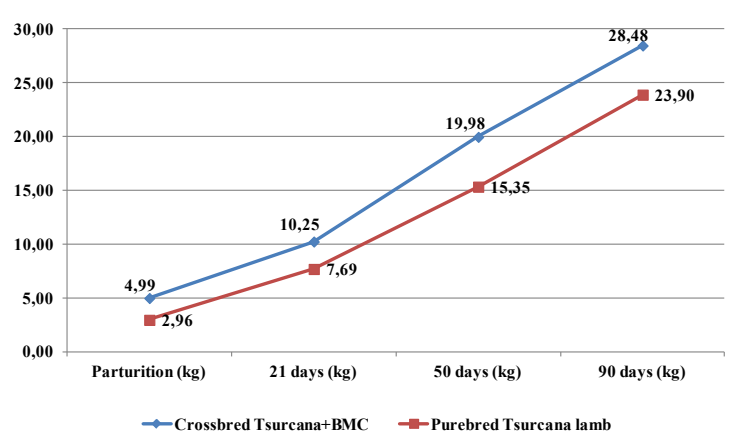

Fig. 2. The body mass average evolution of Tsurcana crossbred and Blanc du Masiff Central and purebred Tsurcana lambs

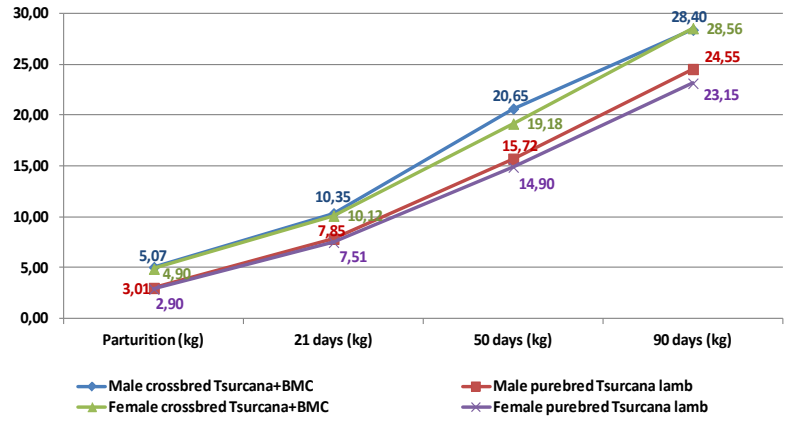

Fig. 3. The body mass average evolution of male and female crossbred Tsurcana and Blanc du Masiff Central and Tsurcana purebred lambs

Tab. 2. ANOVA Test for body weight at parturition for Tsurcana purebreds and crossbreds

\begin{tabular}{|c|c|c|c|c|c|c|}
\hline $\begin{array}{c}\text { Inova: Single Factor } \\
\text { SUMMARY }\end{array}$ & & & & & & \\
\hline Groups & Count & Sum & Average & Variance & & \\
\hline Column 1 & 46 & 229,58 & 4,990869565 & 0,958199227 & & \\
\hline Column 2 & 48 & 142,22 & 2,962916667 & 0,15996578 & & \\
\hline \multicolumn{7}{|l|}{ ANOVA } \\
\hline Source of Variation & $S S$ & $d f$ & $M S$ & $F$ & P-value & $F$ crit \\
\hline Between Groups & 96,60218354 & 1 & 96,60218354 & 175,5107579 & 4,83657E-23 & 3,944538679 \\
\hline Within Groups & 50,63735688 & 92 & 0,550406053 & & & \\
\hline Total & 147,2395404 & 93 & & & & \\
\hline
\end{tabular}

hypothesis that the body weight at parturition of the crossbred Tsurcana lambs are different that the weight of purebred Tsurcana lambs (table 3).

For the body weight of the lambs at 21 days the ANOVA test revealed that $\mathrm{F}>\mathrm{F}$ crit, in our case $53.66>3.94$, the $\mathrm{H}_{0}$ hypothesis is rejected and the
$\mathrm{H}_{1}$ hypothesis is accepted. The $\mathrm{H}_{1}$ hypothesis states that the body weight at 21 days of the crossbred Tsurcana lambs with BMC is different to the weight of purebred Tsurcana lambs. (table 4)

The $\mathrm{t}$-Test analysis revealed that $\mathrm{t}$ Stat $\geq \mathrm{t}$ Critical two-tail, in our research $7.02 \geq 2.00$, that 
Tab. 3. t-Test for body weight at parturition for Tsurcana purebreds and crossbreds

t-Test: Two-Sample Assuming Unequal Variances

\begin{tabular}{ccc}
\hline & Variable 1 & Variable 2 \\
\hline Mean & 4,990869565 & 2,962916667 \\
\hline Variance & 0,958199227 & 0,15996578 \\
\hline Observations & 46 & 48 \\
\hline Hypothesized Mean Difference & 0 & \\
\hline df & 59 \\
\hline t Stat & 13,04614171 & \\
\hline $\mathrm{P}(\mathrm{T}<=$ t) one-tail & $2,4521 \mathrm{E}-19$ & \\
\hline $\mathrm{t}$ Critical one-tail & 1,671093033 & \\
\hline $\mathrm{P}(\mathrm{T}<=\mathrm{t})$ two-tail & $4,90419 \mathrm{E}-19$ & \\
\hline $\mathrm{t}$ Critical two-tail & 2,000995361 & \\
\hline
\end{tabular}

Tab 4. ANOVA Test for body weight at 21 days for Tsurcana lambs with BMC and Tsurcana purebreds

Anova: Single Factor

SUMMARY

\begin{tabular}{|c|c|c|c|c|c|c|}
\hline Groups & Count & Sum & Average & Variance & & \\
\hline Column 1 & 46 & 471,3 & 10,24565217 & 5,086091787 & & \\
\hline Column 2 & 48 & 369,3 & 7,69375 & 0,709534574 & & \\
\hline \multicolumn{7}{|l|}{ ANOVA } \\
\hline Source of Variation & SS & $d f$ & $M S$ & $F$ & $P$-value & F crit \\
\hline Between Groups & 152,9675318 & 1 & 152,9675318 & 53,66826283 & $8,86232 \mathrm{E}-11$ & 3,944538679 \\
\hline Within Groups & 262,2222554 & 92 & 2,850241907 & & & \\
\hline Total & 415,1897872 & 93 & & & & \\
\hline
\end{tabular}

body weight at 21 days of the crossbreds Tsurcana lambs with BMC is different to Tsurcana purebreds lambs. (Table 5).

The statistical analysis with ANOVA single factor at 50 days for the lambs in the two batches revealed that $\mathrm{F}>\mathrm{F}$ crit, in our study being 43.43 $>3.94$ and confirms the hypothesis that the body weights of Tsurcana lambs is not equal to those of the purebred Tsurcana lambs. (table 6)

The t-Test at the data collected at 50 days reinforced the results obtained with ANOVA ( $\mathrm{t}$ Stat $\geq$ t Critical two-tail: $6.48 \geq 2.00$ ) (table 7).

The data collected at 90 days for the body weights of the lambs from the two batches were analyzed with ANOVA and revealed that $42.80>$ 3.94 ( F > F crit) and confirms the hypothesis $\left(\mathrm{H}_{1}\right)$ that the body weight of the purebred Tsurcana lambs is different to those of crossbred Tsurcana with BMC lambs. The results obtained with ANOVA are confirmed also with t-Test: $t$ Stat $\geq t$ Critical two-tail $(6.45 \geq 2.00)$ (table 8, 9).

In the literature, there were no other similar studies to compare our results with. There are studies for the purebreds Tsurcana and purebred Blanc de Massif Central, or in crossings with other breeds, but this is the first research that records the results between the two breeds. The data recorded in the study for the purebred 
Tab 6. ANOVA Test for body weight at 50 days for Tsurcana lambs with BMC and Tsurcana purebreds

Anova: Single Factor

SUMMARY

\begin{tabular}{ccccccc}
\hline Groups & Count & Sum & Average & Variance & & \\
\hline Column 1 & 46 & 919 & 19,97826087 & 20,9884058 & & \\
\hline Column 2 & 48 & 736,7 & 15,34791667 & 2,599570035 & & \\
\hline ANOVA & \multicolumn{7}{c}{} & & & & \\
\hline Source of Variation & SS & df & MS & F & P-value & F crit \\
\hline Between Groups & 503,6139687 & 1 & 503,6139687 & 43,43705559 & $2,69663 \mathrm{E}-09$ & 3,944538679 \\
\hline Within Groups & 1066,658053 & 92 & 11,59410927 & & & \\
\hline & \multicolumn{7}{c}{} & & \\
\hline Total & 1570,272021 & 93 & & & \\
\hline
\end{tabular}

Tab 5. t-Test for body weight at 21 days for Tsurcana lambs with BMC and Tsurcana purebreds

t-Test: Two-Sample

Assuming Unequal

Variances

\begin{tabular}{ccc}
\hline & Variable 1 & Variable 2 \\
\hline Mean & 10,24565217 & 7,69375 \\
\hline Variance & 5,086091787 & 0,709534574 \\
\hline Observations & 46 & 48 \\
\hline $\begin{array}{c}\text { Hypothesized } \\
\text { Mean Difference }\end{array}$ & 0 & \\
\hline $\mathrm{df}$ & 57 & \\
\hline $\mathrm{t}$ Stat & 7,20780897 & \\
\hline $\mathrm{P}(\mathrm{T}<=\mathrm{t})$ one-tail & $7,16659 \mathrm{E}-10$ & \\
\hline $\mathrm{t}$ Critical one-tail & 1,672028889 & \\
\hline $\mathrm{P}(\mathrm{T}<=\mathrm{t})$ two-tail & $1,43332 \mathrm{E}-09$ & \\
\hline $\mathrm{t}$ Critical two-tail & 2,002465444 \\
\hline
\end{tabular}

Tab. 7. t-Test for body weight at 50 days for Tsurcana lambs with BMC and Tsurcana purebreds

t-Test: Two-Sample Assuming Unequal Variances

\begin{tabular}{ccc}
\hline & Variable 1 & Variable 2 \\
\hline Mean & 19,97826087 & 15,34791667 \\
\hline Variance & 20,9884058 & 2,599570035 \\
\hline Observations & 46 & 48 \\
\hline $\begin{array}{c}\text { Hypothesized } \\
\text { Mean Difference }\end{array}$ & 0 & \\
\hline $\mathrm{df}$ & 56 & \\
\hline $\mathrm{t}$ Stat & 6,481063644 & \\
\hline $\mathrm{P}(\mathrm{T}<=\mathrm{t})$ one-tail & $1,24104 \mathrm{E}-08$ & \\
\hline $\mathrm{t}$ Critical one-tail & 1,672522304 \\
\hline $\mathrm{P}(\mathrm{T}<=\mathrm{t})$ two-tail & $2,48208 \mathrm{E}-08$ & \\
\hline $\mathrm{t}$ Critical two-tail & 2,003240704 & \\
\hline
\end{tabular}

Tab. 8. ANOVA Test for body weight at 90 days for Tsurcana lambs with BMC and Tsurcana purebreds Anova: Single Factor SUMMARY

\begin{tabular}{ccccccc}
\hline Groups & Count & Sum & Average & Variance & & \\
\hline Column 1 & 46 & 1309,9 & 28,47608696 & 19,18852657 & & \\
\hline Column 2 & 48 & 1147,4 & 23,90416667 & 4,080407801 & & \\
\hline ANOVA & \multicolumn{7}{c}{ PS } & & & & \\
\hline Source of Variation & SS & $d f$ & MS & & \\
\hline Between Groups & 490,9853292 & 1 & 490,9853292 & 42,805117 & $3,35962 \mathrm{E}-09$ & 3,944538679 \\
\hline Within Groups & 1055,262862 & 92 & 11,4702485 & & & \\
\hline \multicolumn{7}{c}{} \\
\hline Total & 1546,248191 & 93 & & & & \\
\hline
\end{tabular}


Tab. 9. t-Test for body weight at 90 days for Tsurcana lambs with BMC and Tsurcana purebreds

t-Test: Two-Sample Assuming Unequal Variances

\begin{tabular}{ccc}
\hline & Variable 1 & Variable 2 \\
\hline Mean & 28,47608696 & 23,90416667 \\
\hline Variance & 19,18852657 & 4,080407801 \\
\hline Observations & 46 & 48 \\
\hline Hypothesized Mean Difference & 0 & \\
\hline df & 63 & \\
\hline t Stat & 6,45181273 & \\
\hline $\mathrm{P}(\mathrm{T}<=\mathrm{t})$ one-tail & $8,92586 \mathrm{E}-09$ & \\
\hline $\mathrm{t}$ Critical one-tail & 1,669402222 & \\
\hline $\mathrm{P}(\mathrm{T}<=\mathrm{t})$ two-tail & $1,78517 \mathrm{E}-08$ & \\
\hline $\mathrm{t} \mathrm{Critical} \mathrm{two-tail}$ & 1,998340522 & \\
\hline
\end{tabular}

Tsurcana sheep were similar to those found by other researchers (Miresan et al., 1979). For the crossbreds, the productions were superior compared with purebreds, but similar to other crossbreds with meat breeds used to enhance the meat production (Pascal et al., 2014).

\section{CONCLUSION}

More than half of the lambs were males (54,35\% crossbred lambs and 54,17\% purebred lambs), and the share almost equals were females $45,65 \%$ crossbreds lambs and $45,83 \%$ of purebreds Tsurcana lambs.

There are statistical differences at $\mathrm{p}=0.05$ between the weights at parturition, at 21, 50 and 90 days of crossbred Tsurcana with Blanc de Massif Central lambs and purebreds Tsigaia lambs.

Concerning the birth weights, at 21, 50 and 90 days the results showed a difference between the pure breed lambs and the crossed lambs. The daily weight gain was superior in the crossed lambs compared with purebred lambs. The research confirmed the superior weights of lambs obtained in the first generation between the BMC and Tsurcana breed.

Acknowledgements: This work has benefited from financial support through the PN-II-PT-
PCCA-2013-4-1239 project, No: 152/01.07.2014, "Obtaining the Romanian meat lamb - OVICARO".

\section{REFERENCES}

1. Belibasaki S, Sossidou EN, Gavojdian D (2012). Local Breeds: Can they be a Competitive Solution for Regional Development in the World of "Globalization"? The Cases of Greek and Romanian Local Breeds, Scientific Papers: Animal Science and Biotechnologies, 45 (2): 278-284.

2. Dodouet C (2003). La production du mouton, $2^{\mathrm{e}}$ edition, Ed France Agricole, Paris.

3. FAO STATISTICAL YEARBOOK (2014). Europe and Central Asia Food and Agriculture, Food and Agriculture Organization of the United Nations Regional Office for Europe and Central Asia Budapest, E-ISBN 978-92-5108168-6.

4. Kukovics S, Németh T , Lengyel A, Toldi G, Jávor A (2013). The Effects Of Genotype And Fattening Technology On Meat Producton Characteristics, Lucrări Știinţifice-Seria Zootehnie, vol. 59 (18).

5. Mireșan E, Pop A, Popa O (1979). Contribuții la cunoașterea aptitudinilor pentru producţia de carne a raselor Merinos de Transilvania, Țigaie și Ţurcană. Lucr.Șt. I.A.C.N., vol. 2: 143-146.

6. Pascal C, Nechifor I (2014). The effect of crossing romanian sheep breeds with rams of meat breeds over the specific indicators of meat production, Lucrări Ştiinţifice - Seria Zootehnie, vol. 61.

7. Reports of the Romanian National Agency for Genetic Improvement and Reproduction in Animal Husbandry for the year 2010, (2010). Retrieved on 5 March 2012 from: http://www.anarz.eu /Anarz Administrator Site/ CMS Content/ RAPORT\% 20DE\% 20ACTIVITATE/ Raport. 